\title{
一対比較によるショケ積分の被樍分関数 （入力值）の同定についで
}

高萩 栄一郎*

本稿では，一対比較法を使ったショケ積分の被積分関数 $f$ (入力值) の同定方法を提案する.AHPなど で使われる一対比較で, 程度を表すことばと一対比較值の対応表は，多くの場合，固定した值が設定され る。まず，簡単な実験を行い，一対比較の対象により対応表のパラメータが異なることを示す。ショケ積 分の入力值は, すべての評価項目で同じ評価単位を持たなくてはならない. そこで, 入力值の同定者には, 一対比較の回答の他に, 理想点と満足点の要素を回答させる. 対応表のパラメータを調節することにより, 満足点と理想点の評価值をすべての評価項目で揃え，同じ評価単位を持つという条件を満足させる．最後 に，評価対象がとりうる值の集合が有限離散集合の場合とLogit 回帰にあてはめた連続值の場合の同定例 を示す。

キーワード：ショケ積分, 評価単位, 一対比較法, 満足点, 理想点

\section{1. はじめに}

ファジィ積分の研究において, ファジィ測度の同定 の研究は盛んに行われている。しかし，ファジィ積分 の入力值の研究は少ない. 線型の回帰分析や加重和と は異なり，ショケ積分をはじめファジィ積分の場合の 入力值間の条件は厳しい。そこで，本稿は，一対比較 を使って，この条件を満したショケ積分の被積分関数 (入力值)を求める方法を提案する。

本稿では, 図 1 のように, $m$ 個の評価基準の入力値 を求め, ショケ積分により総合評価值を求めるとき, 各入力值を一対比較を使って同定する方法を考察す る.

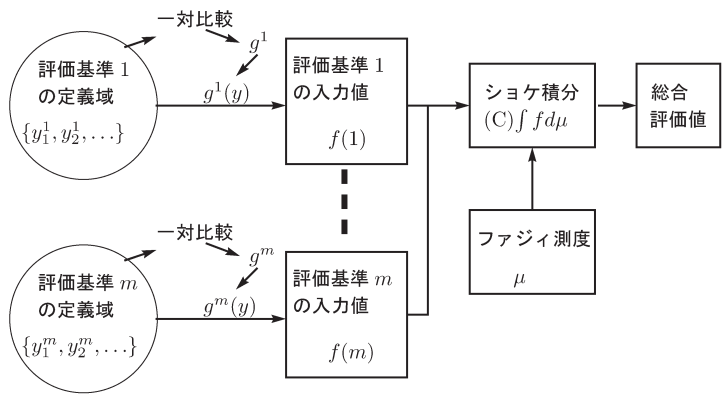

図 1 概略

\footnotetext{
$\dagger$ Identifying $f$ in Choquet Integral (C) $\int f d \mu$ using Pairwise Comparision Eiichiro TAKAHAGI

* 専修大学商学部

Sneshu University, School of Commerce
}

本研究のきっかけとなった課題は, ショケ積分を 使ったデータ検索システムの各評価基準の入力值をど のように同定するかである。入力值 $f(i)$ は，利用者の 希望条件とデータベースに記憶された值から求める。 例えば，家債の希望条件が70,000円で，あるレコード の家賃が71,000円のとき，その入力值を求める。これ は, 図 1 のように, 各評価基準の值が取りうる範囲を 定義域 $\left(Y^{k}\right)$ とし，AHPなどで用いられる一対比較法 を用いて, 入力值を求める関数 $g^{k}$ (個別評価関数)を 求めることである.

ある評価基準について，「満足する」というファジィ 集合を考えれば，この個別評価関数は，そのメンバー シップ関数に対応する。一対比較法を用いてメンバー

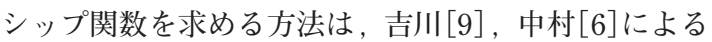
と, 比較評定法のなかの比率評定法に分類されてい る、AHPを利用している方法としては，例えば，竹 田[7]では, AHPの一対比較法で, 重要度を求め, メ ンバーシップ関数を同定している。また，中村 [6] は, メンバーシップ関数の同定に一対比較を用いると き，「固有べクトルのスケーリングの問題が存在する」 としている.

2 節では，AHPの「ことばと一対比較值の対応表」 (表 1 )で，「その中間」を含めて 1 間隔で等差的な数值 を割り当てている。矢の数值差は状況に依存すること を実験により示す。 3 節では, ショケ積分の入力值が 満たさなくてはならない条件を考察し，4節では， 2 節の数值差を利用してショケ積分の入力值を計算する 個別評価関数の同定方法を提案する。 5 節では, 評価 
基準の定義域が有限集合の場合の同定方法を具体例を 使い説明する。6 節では, 評価基準の定義域が連続值 の場合について，個別評価関数を線型の関数もしくは Logit曲線に近似にすることにより同定する.

\section{1 記号・問題}

評価基準の集合を $X=\left\{x_{1}, x_{2}, \ldots, x_{m}\right\}$ とする. たと えば，賃貸住宅の総合評価では $X=\{$ 家賃，間取り， 駅からの時間 $\}$ となる. $f(k) \in[0,1], k=1, \ldots, m$ を ショケ積分の被積分関数 (入力值) とする.

ファジィ測度 $\mu$ は，一般的な定義に従い，

$\mu(A) \in[0,1], \forall A \in 2^{X}$ :

$A \subseteq B$ ならば $\mu(A) \leq \mu(B)$.

$\mu(\emptyset)=0, \mu(X)=1$

と定義する。本稿では，ファジィ測度 $\mu$ の同定につ いては議論せず，所与とする。ショケ積分は，一般的 な定義に従い，

(C) $\int f d \mu \equiv \int_{0}^{\infty} \mu(\{x ; f(x)>r\}) d r$

で定義する.

各評価基準は，その評価基準が取り得る值の集合 (定義域)を持つ. $k$ 番目の評価基準の定義域を $Y^{k}=$ $\left\{y_{1}^{k}, y_{2}^{k}, \ldots\right\}$ で表す。たとえば，家賃という評価基準の 定義域は， $Y^{1}=\{y ; 0<y\}$ となり，間取りの定義域 は, $Y^{2}=\{2 \mathrm{~K}, 2 \mathrm{DK}, 1 \mathrm{LDK}, 3 \mathrm{DK}\}$ のようになる。

本稿の目的は, 評価基準 $k$ の定義域 $Y^{k}$ から 1 つ要 素を取り出し, その值から, 被積分関数 (入力值) $f(k)$ に変換する関数 $g^{k}$ を求めることである.

$g^{k}: Y^{K} \rightarrow[0,1]$

たとえば，間取りが2LDKのレコードの間取りの入力 值は, $f(2)=g^{2}(2 \mathrm{LDK})$ となる。この $g^{k}$ を $k$ 番目の個 別評価関数と呼ぶ.

すべての $g^{k}$ を同定し， ある総合評価対象を決め， その $k$ 番目の評価基準の值が $y \in Y^{k}$ のとき，

$f(k)=g^{k}(y)$

で入力值を定め, ショケ積分により総合評価值を求め る.

\section{2.一対比較值は可変}

表 1 のAHPの列は, AHPで使われることばに対す る一対比較值である。一対比較值は, 何倍よいのかを
表 1 ことばと一対比較值の対応表

（[2]のことばを利用）

\begin{tabular}{|c|c|c|c|c|}
\hline ことば & AHP & $\begin{array}{l}\text { 等差 } \\
s: \text { 公差 }\end{array}$ & 等比 & $\begin{array}{l}\text { 回答値 } \\
c_{i j}\end{array}$ \\
\hline 絶対的によくない & $1 / 9$ & $1 /(1+8 s)$ & $1 / r^{8}$ & -8 \\
\hline : & : & : & : & : \\
\hline おなじくらい & 1 & 1 & 1 & $\dot{0}$ \\
\hline (その中間) & 2 & $1+s$ & $r^{2}$ & 1 \\
\hline 若干よい & 3 & $2+s$ & $r^{3}$ & 2 \\
\hline : & : & : & & : \\
\hline 絶対的によい & 9 & $1+8 s$ & $r^{8}$ & 8 \\
\hline
\end{tabular}

表す值である。たとえば, 一対比較の対象 $(\mathrm{A})$ と (B) を比べて,「(A)が若干よい」と回答したとき, AHPで は, 「(A)が (B)に比べて 3 倍よい」と回答したものと している.AHPでは, 通常, 表 1 のAHPの列のよう に固定した值であるが，この值は，状況などにより， 利用者が持っている值が異なるのではないかと考え た。そこで，中島 [5]の考察やHarker[4]の実験をふ まえ, 2.1節の実験を行い, 表右の等差的, 等比的な 間隔で, 公差 $(s)$ や公比 $(r)$ が状況により異なることを 示す.

\section{1 実験}

実験は, 日本の道州面積 (IA ; 刀根 $[2])$ と関東地方 の都県の面積 (IB) に関する一対比較のアンケートを 行った.

被 験 者：専修大学の学生34名

実験間隔：IAの 1 週間後にIBの実験を行った。

\section{実験方法 :}

・IAでは，道州の白地図を見せ，道州(北海 道, 本州, 四国, 九州)の面積の大きさに ついて一対比較を行った。

・IBでは, 関東地方の都県の白地図を見 せ, 各都県 (東京, 神奈川, 千葉, 埼玉) の面積の大きさについての一対比較を 行った。

・回答は, 図 2 のような用紙に, 左右の 2 項目のみを考元, 該当する部分に○をつ けるように教示した。「よい」は，「大き い」に読み替えるように指示した。

$c_{i j}$ をある被験者, ある一対比較の代替案 $i$ と $j$ の 回答值 (表 1 ) とする。罒 2 の回答から $c_{i j}$ の值を読及取 る。本州を 2 , 四国を 3 , 九州を 4 とすると, 図 2 の 田から $c_{23}=8$, 回から $c_{34}=-2$ とする. 


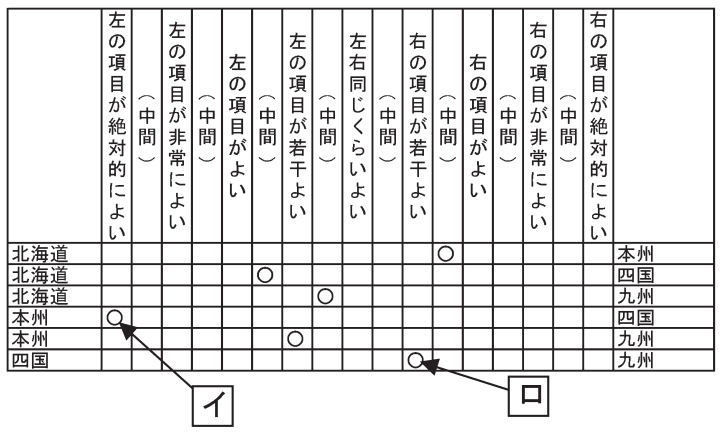

図 2 日本の道州の面積の一対比較

\section{2 実験結果と考察}

各人のそれぞれの一対比較の回答值 $\left(c_{i j}\right)$ から次の手 順で, 真の面積の割合にもっとも当てはまる $s$ とを 求めた. ただし, 真の面積の大小関係と回答の一対比 較から求めた面積の大小関係が異なる一対比較の回答 は，集計から除外した。等差的な場合と等比的な場合 で求め方はほとんど同じであるので，*は， $s$ または $r$ とする.

（1） $s$ または $r$ を固定して, 一対比較值を求める.

等差的 $a_{i j}= \begin{cases}1+s c_{i j} & \text { if } c_{i j} \geq 0 \\ \frac{1}{1-s c_{i j}} & \text { other cases }\end{cases}$

等比的 $a_{i j}=r^{c_{i j}}$

（2） $a_{i j}$ から一対比較行列 $A$ を作成し, 固有值法で ウエイト $w_{1}, \ldots, w_{n}(n$ は一対比較の対象の数, $\left.\sum_{i=1}^{n} w_{i}=1\right)$ を求める.

（3）真のウエイト(面積の割合, $w_{1}^{+}, \ldots, w_{n}^{+}, \Sigma_{i=1}^{n} w_{i}^{+}$ =1) と (2) で求めたウエイトの差異の二乗和を 求める.

$d(*)=\sum_{i=1}^{n}\left(w_{i}-w_{i}^{+}\right)^{2}$

（4）（1）の $s$ または, $r$ を変化させて, 最小の $d(*)$ となる $s$ または $r$ を探す。

四 3 と 4 は, 日本の道州と関東の都県の面積につい て, 各サンプルのもっとも当てはまる $s, r$ を求め, その度数分布図である。 4 つの度数分布表から明らか なように, 日本の道州の場合の方が $s, r$ とも大き い. 回答者は状況によって, 公差 $(s)$ または公比 $(r)$ を 変えていると推測される. IA の $r$ の平均值1.34の「絶
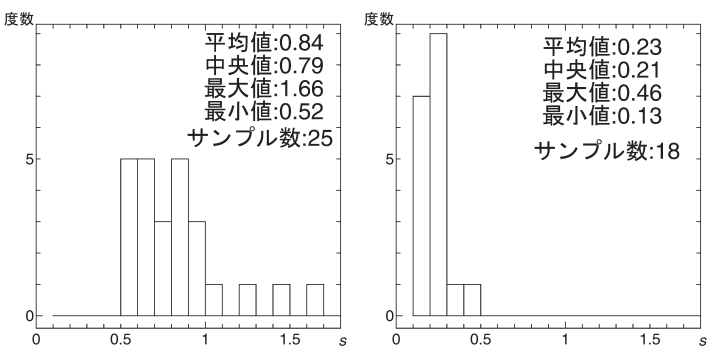

図 $3 s$ の分布 (左 IA，右 IB)
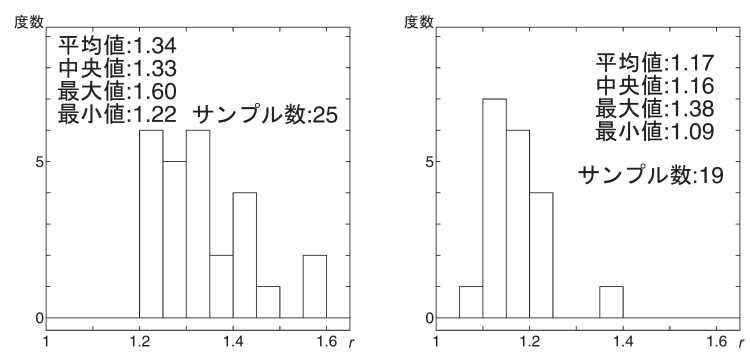

図 $4 r$ の分布（左 IA，右 IB）

対的」に換算した $1.34^{8}=10.4$ とIBの $1.17^{8}=3.51$ 考え ると，㶢れぞれの面積の最大の差異， $-\mathrm{IA} の 12.3$ 倍， IBの2.3倍一と関係があると考えられる。したがって， 状況によって, $r($ または $s$ ) は異なると考えられる.

また, Harkerの実験[4]結果と同じように, 等差的 に割り当てた方が当てはまりがよかった。

\section{3. ショケ積分の入力値}

[8]で指摘したように, ショケ積分の入力值 $f$ (被積 分関数) は次のような制約を満たしていなくてならな い.

・入力值は間隔尺度であること.

・ショケ積分の入力值は, 穴の定義により, 他の評 価基準の入力值と減算をしている。 そのため, 他 の入力值との大小関係(順位)も重要である.

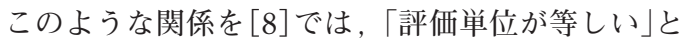
呼んでいる。また, 効用理論では, 「strong commensurability」と呼ばれている.

一対比較で求めた(個別) 評価值の尺度は比例尺度で あることが知られている $[4]$ 。したがって, (個別)評 価值は間隔尺度である。ファジィ積分の入力值にする にはさらに次の 2 つの条件が必要である。

条件 I : 入力値の間隔の単位がすべての評価基準で 同じであること すべての評価基準で同じ入力值の差 
は同じ満足度の差を意味し，その差の $t(>0)$ 倍も $t$ 倍 の満足度の差をあらわす。この条件は, AHPなどで の加重平均でも満たさなくてはならない。たとえば, 表 2 のケース I の単純平均(等重み)では，（イ）から (口)の評価基準 $\mathrm{A}$ の 0.2 の増大は, $\mathrm{B}$ の 0.2 の減少で, 同じ出力 (単純平均值) となる。 0.2 の出力への影響 は，等重みの場合，同じになる。

ケース IIIの場合，Aと Bの重みの比は $2 ： 1$ とす る。(ハ)から(ニ)への0.1の増大で, (二)が同じ出力 にするには，Bでは 2 倍必要になり，0.2の減少でなく てはならない。

表 2 評価単位の問題

\begin{tabular}{|c|c|c|c|c|c|}
\hline \multirow[b]{2}{*}{ ケース I } & \multicolumn{2}{|c|}{ 評価基準 } & \multirow{2}{*}{$\begin{array}{l}\text { 単純 } \\
\text { 平均 }\end{array}$} & \multicolumn{2}{|l|}{ ショケ } \\
\hline & A & B & & 積分值 & 順位 \\
\hline データ (イ) & 0.5 & 0.8 & 0.65 & 0.56 & 2 \\
\hline データ (ロ) & 0.7 & 0.6 & 0.65 & 0.62 & 1 \\
\hline \multirow[b]{2}{*}{ ケース II } & \multicolumn{2}{|c|}{ 評価基準 } & 単純 & \multicolumn{2}{|l|}{ ショケ } \\
\hline & A & B & 平均 & 積分值 & 順位 \\
\hline データ (イ') & 0.5 & 0.4 & 0.45 & 0.42 & 1 \\
\hline データ (ロ') & 0.7 & 0.2 & 0.45 & 0.30 & 2 \\
\hline \multicolumn{2}{|c|}{ ケース III } & $\mathrm{A}(2)$ & $\mathrm{B}(1)$ & \multicolumn{2}{|c|}{ 加重平均 } \\
\hline \multicolumn{2}{|c|}{ データ (ハ) } & 0.5 & 0.8 & \multicolumn{2}{|l|}{0.6} \\
\hline \multicolumn{2}{|c|}{ データ(二) } & 0.6 & 0.6 & 0.6 & \\
\hline
\end{tabular}

口条件 II：すべての評価基準で，同じ入力值であれば 同じ満足度であること 加重和では, 入力值は条件 I が必要であったが，ショケ積分の入力值では，この条 件 II も必要である。例えば，表 2 のケース I， II で は，ケース II の評価基準 $\mathrm{B}$ の入力值が一律に 0.4 小さ くなっている.この場合, ケース I での平均值はとも に0.65であり，ケースIIでは，ともに0.45で同じであ る. 表 2 右は, ショケ積分を扒こなったものである. ただし，ファジィ測度は，AとBは，等重みになるよ うに,

$$
\begin{array}{r}
\mu(\emptyset)=0, \mu(\{A\})=\mu(\{B\})=0.2, \\
\mu(\{A, B\})=1.0
\end{array}
$$

とした。評価基準 $\mathrm{B}$ の入力值を一律に 0.4 下げたこと により，ファジィ積分值の順位が変動している。 ショ ケ積分の場合, 各評価基準の入力值の差とファジィ測 度の積を用いる。例の場合のように, 2 入力 $(f(A)$, $f(B))$ の場合,

$$
\begin{array}{r}
(f(A)-f(B)) \mu(\{A\})+f(B) \mu(\{A, B\}) \\
f(A) \geq f(B) \text { の場合 }
\end{array}
$$

$$
\begin{array}{r}
(f(B)-f(A)) \mu(\{B\})+f(A) \mu(\{A, B\}) \\
h(A)<h(B) \text { の場合 }
\end{array}
$$

となる。このように, $\min (f(a), f(b))$ や $f(a)-f(b)$ の值を使っているので, $f(a)$ や $f(b)$ の大小関係が重 要になる。一律に入力值を増減させると, 積をとる ファジィ測度の值が異なることになる。したがって， 同じ入力值であれば，同じ満足度でなくてはならな い.

\section{4. 提案手法}

一対比較を利用して，ファジィ積分の各評価基準 $k$ の入力值 $f(k)$ を求める個別評価関数 $g^{k}$ を求める. 本 節では, $Y^{k}$ が有限集合であり, 要素数が 2 から 7 程 度で $Y^{k}$ のすべての要素間で一対比較が可能な場合で 説明する。その他の場合は，次節以降で説明する。

一対比較で求めたウエイト $w_{i}^{*}\left(\Sigma_{i} w_{i}^{*}=1\right)$ を, その まま $g^{k}\left(y_{i}^{k}\right)=w_{i}^{*}$ とすると, 必ずしも 3 節の 2 つの条 件を満たしていない，たとえば， $Y^{1}$ と $Y^{2} て ゙ ，$ 要素の 数が極端に異なる場合, 和を 1 にする正規化により, 要素の数が大きな評価基準の $w^{*}$ の差は相対的に小さ

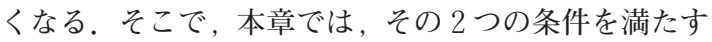
ように, $w^{*}$ を $t_{k}>0$ 倍し,$g^{k}\left(y_{i}^{k}\right)=t_{k} w_{i}^{*}$ で求めるため のパラメータ $t_{k}$ と 2 節で読明した $s$ または $r$ を同定 する方法を考察する。

\section{1 考元方}

まず，一対比較の対象の集合 $Y^{k}$ の中から次の 2 点 の要素を選ぶ.

理想点（１）ほぼ理想的な要素。 $y_{I}^{k}$, この個別評価 関数の值を $e_{I}($ 例えば，0.95または1.0)と する $\left(g^{k}\left(y_{I}^{k}\right)=e_{I}\right)$.

満足点 $(G)$ 理想的ではないが, 満足できる要素 $y_{G}^{k}$. この要素の個別評価関数の值を $e_{G}$ (例えば，0.7または 0.8 ) となるように同 定する $\left(g^{k}\left(y_{G}^{k}\right)=e_{G}\right)$.

各評価基準の理想点の入力值, 満足点の入力值は同じ になるように, 理想点, 満足点の要素を選ぶ.

たとえば, 賃貸住宅の総合評価で, 満足点を正の評 価と負の評価の境界点とする。正の評価とは，この評 価基準で評価した場合，借りたいと思う物件であり， 負の評価とは借りたくない物件になることである。家 顀の満足点が 6 万であれば，6万より高い物件は借り 
たくなくなる。すべて満足点の物件 $(6$ 万， 12 分,$\ldots$ ) は，借りたいと思う最低の総合評価值の物件になる。

理想点は，たとえば，それ以上よい条件を求めない 点とする．たとえば，家賃の理想点を 4 万としたら， まだ余裕があるので，もう少し他の条件がよい物件を 探したほうがよいと思う点とする。

\section{2 個別評価関数の求め方}

$k$ 番目の評価基準の個別評価関数 $g^{k}$ を求める。一 対比較の対象の要素を $y_{1}^{k}, \ldots, y_{n}^{k}$ とする。 ただし，その 中に理想点 $y_{I}^{k}$, 満足点 $y_{G}^{k}$ を含むように選ぶ. 次に, この要素間の一対比較を行い, その回答值を $c_{i j}$ とす る. ある適当な $s>0$ または $r>1$ から始め, 次の手 順で各要素の入力值を求める。

（1） $s$ または $r$ に基づき, 一対比較の回答値 $\left(c_{i j}\right)$ か ら, 式(7)または (8)を用いて, $a_{i j}$ を求め, 一 対比較行列 $A$ を作成する. $A$ の最大固有值, そ れに対応する固有べクトル $\left(w_{1}, \ldots, w_{n}, \sum_{i}^{n} w_{i}=1\right)$ を求める.

（2）（1）で求めた理想点のウエイトを $w_{I}$ とし,$t=e_{I}$ $/ w_{I}$ とし, 各要素の $w_{i}^{*}, i=1, \ldots, n$ を求める.

$$
w_{i}^{*}=w_{i} \times t, i=1, \ldots, n
$$

(3) $w_{i}^{*}, \ldots, w_{n}^{*}$ のうち満足点の要素の入力值を $w_{G}^{*}$ と し, 満足值 $e_{G}$ と比較する.

$w_{G}^{*}>e_{G} \quad s$ または $r$ を増大させ，(1)へ。

$w_{G}^{*}<e_{G} s$ または $r$ を減少させ, $(1)$ へ.

$w_{G}^{*}=e_{G}$ このときの $s$ または $r$ を採用する.

実際には, 2 分検索などで, 満足点の入力值と満足值 がほぼ致する点を求める. $w_{G}^{*}=e_{G}$ のときの $w_{i}^{*}$ 入力值とする.

$g^{k}\left(y_{i}^{k}\right)=w_{i}^{*}, i=1, \ldots, n$

\section{3 ファジィ積分の入力値の条件との関係}

このようにして求めた各評価基準の理想点と満足点 に打ける満足度は等しい。すべての評価基準で，理想 点の評価值 $\left(e_{I}\right)$ と満足点の評価值 $\left(e_{G}\right)$ は等しいので, それらの評価值の差 $\left(e_{I}-e_{G}\right)$ も等しい. したがって, $w_{i}^{*}$ が間隔尺度であることと合わせて考えると, 入力 值間の間隔の単位はすべての評価基準で同じになり, 条件 Iを満たす。また, 満足点(または理想点)の満足 度がすべての評価基準で同じことと条件 I を合わせれ ば条件 II も満たしていることがわかる。したがって, この提案手法で求めた入力值は， 3 節で示した条件を
満たしている.

\section{4 同定者と一対比較の被験者が異なる場合}

上記の議論では, 理想点の要素, 満足点の要素, そ の他の一対比較対象の要素の選択および一対比較の回 答は，すべて同定者一人で行うことを前提している. しかし，アンケート調查などで一対比較対象の要素の 選択などが難しい場合がある。その場合, 要素の選択 は事前にアンケート実施者が行い, 被験者は, 理想点 と満足点の選択と一対比較を行う,

\section{5 実際上の扱い}

一対比較を行った結果, 理想点以外の要素のウエイ トが理想点の要素より高くなることもあり得る。実際 上の扱いとしては, その理想点よりよい要素を理想点 として扱うことにより対処できる４.2節の (1)でその ような現象が生じたときは，(1)の時点で入れ替える ことが可能である。

満足する要素のうち, 最低の満足度の要素を 1 つだ け示すのが困難な場合がある。その場合, 満足できる もの(正の評価の要素)をすべて列挙し，(1)のウエイ 卜を計算した時点で, 列挙した要素のうち, もっとの 低い $w_{i}$ の要素を満足点とすることができる.

全要素で「同じくらいよい」と回答した場合, 本手法 では同定不可能である。しかし，このような場合, 満 足点の要素が入っていれば, すべて満足点の值 $e_{G}$ を 与えることで対処できる。

一対比較の回答に欠損值が含まれている場合, Harkerの方法 [3]で, ウエイトを求めることができ る. 久損值が許される範囲は, すべての要素間の一対 比較が間接的にされていれば, 同定可能である.

\section{6 求められない $s$ が存在する}

等差的に $s$ を割り当てる場合, 理想点, 満足点の選 び方および一対比較結果によっては， $s$ を求められな い場合がある。例えば， A， B , Cの3つの一対比較 対象で, Aが理想点, Bが満足点とする。このときの 一対比較の回答值が表 3 のようになったとし, $e_{I}=$ $1.0, e_{G}=0.7 に$ ，すなわち， $w_{A}(s)=1, w_{B}(s)=0.7$ になるような $s>0$ を求める。 しかし, $s$ をいくら変 化させても求めることはできない.

表 $3 s$ が求まらない一対比較の回答值 $c_{i j}$

\begin{tabular}{c|ccc} 
& $\mathrm{A}$ & $\mathrm{B}$ & $\mathrm{C}$ \\
\hline $\mathrm{A}$ & 0 & 0 & 8 \\
$\mathrm{~B}$ & & 0 & 7 \\
$\mathrm{C}$ & & & 0
\end{tabular}


あてはまりの度合いは等差的のほうがよかったが (2.1 節)，このように求められない場合があるので, 実際に本手法を用いるときは，等比的を用いた方がよ いだろう。

\section{5．定義域が有限離散集合の場合}

\section{1 同定法}

個別評価関数の定義域が有限離散集合でかつ, 要素 の数が比較的少数(おおよそ 7 以下)の場合，4.2節で

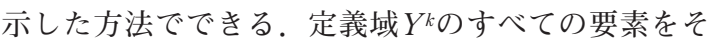
のまま,一対比較対象の要素にする。もつともよい要 素を理想点とし, それ以外の要素で, 満足できる要素 のうち，もっとも満足度が低い要素を満足点の要素と する。

定義域の要素数が多い場合, すべての組み合わせで 一対比較を行うことは事実上不可能である。一対比較 を行わず，直接評価一「とてもよい，よい，すこしよ い，普通，...,とてもよくない」の 7 段階評価などーを 行うことが考えられる。しかし，ファジィ積分の入力 值は，評価単位がすべてそろっていなくてはならな い.すなわち，一対比較を行った評価基準と同様に比 率に意味があること, 理想点と満足点が他の評価基準 と揃っていることが必要である。次のような方法を提 案する。

（1）定義域の要素の中から，もっともよく知ってい る要素など基準となる要素を 1 つ選び, 基準点 とする。

（2）一対比較は，この基準点とのみ行う。すなわ ち, 定義域の要素数 -1 回行う.

(3) 理想点の值が $e_{I}$, 満足点の值が $e_{G}$ になる $r$ (ま たは $s$ )を調整しながら, 基準点の一対比較結 果から久損值を含む一対比較行列を作成する. この久損值を含む一対比較行列から, Harker の方法 [3]などで, 各代替案の入力值を求め る.

各要素の満足度は 1 回の比較で決まるので, 多重比較 に比べて信頼度が低くなる。そのほか，基準点を複数 設けたり，代替案によって基準点を変えるなど様々な 方法が考えられる。

\section{2 間取りの満足度の同定例}

$\left\lceil 2 \mathrm{DK} 」\right.$ を満足点 $\left(e_{G}=0.7\right)$ として, 各間取り $(2 \mathrm{~K}$, $1 \mathrm{LDK}, 3 \mathrm{DK}$ )の満足度を一対比較する(図 5 )。理想 点 $\left(e_{I}=1.0\right)$ は「 $3 \mathrm{DK} 」$ として求めると表 4 のように なった。等差的な場合 $s=0.85$ となり，等比的な場合

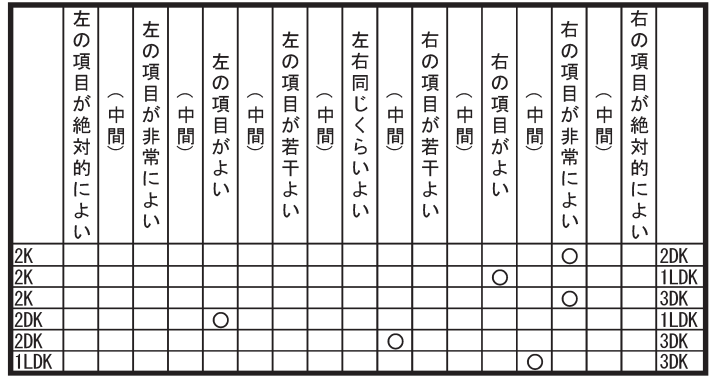

図 5 2DKという希望での一対比較

表 4 各間取りの評価值

\begin{tabular}{|c|c|cccc|}
\hline & $s, r$ & $2 \mathrm{~K}$ & $2 \mathrm{DK}$ & $1 \mathrm{LDK}$ & $3 \mathrm{DK}$ \\
\hline 等差 & $s=0.85$ & 0.10 & 0.70 & 0.25 & 1.00 \\
等比 & $r=1.55$ & 0.05 & 0.70 & 0.16 & 1.00 \\
等差 & $s=1.00$ & 0.09 & 0.67 & 0.22 & 1.00 \\
\hline
\end{tabular}

は, $r=1.55$ となる. $s=1.0$ は, 通常のAHPでの代替 案の評価値である。

\section{6．連続値の場合}

\section{1 同定法}

定義域 $Y^{k}$ が，正の実数全体や実数区間の場合など を考える，連続值を定義域とするメンバーシップ関数 を一対比較で同定する方法としては, 次のような方法 がよく使われる(竹田[7]).

（1）定義域から適当な点を選択し代替案とする。

（2）代替案間の一対比較を行い，固有值法などでウ エイトを求める.

（3）最大の代替案のウエイトが 1 になるように正規 化する。

（4）各代替案のウエイトを直線で結び, メンバー シップ関数とする.

本稿では, 他の評価基準との理想点, 満足点を揃え, 関数にあてはめる。あてはめる関数形は, Logit 曲線 と直線を使用する。

関数の形状は，次の 3 つを考える.

理想方向型 ある方向 (十または一)に值が行けば行く ほざ，個別評価関数の值が大きくなる(図 6 ). たとえば，価格のように安ければ安いほどよい と考えた場合の個別評価関数である.

理想点型 ある 1 点の個別評価関数の值高い場合であ る。(図 7 )。たとえば，最適な室温があり，そ れより高くなっても低くなっても単調に減少す る関数である。 
理想区間型 理想点型の理想点を区間にしたものであ る。たとえば，青年のメンバーシップ関数のよ うに，ある区間で個別評価関数の值がほぼ1の ものである。

個別評価関数には, Logit 曲線

$z=g(y)=\frac{1}{1+\exp (-\alpha-\beta \log y)}$

$(\alpha, \beta$ はパラメータ)または, 線型

$z=g(y)=a y+b$

( $a$, bはパラメータ)を用いる。 Logit 曲線では,

$\log \left(\frac{z}{1-z}\right)=\alpha+\beta \log y$

という $\log y$ と $\log \left(\frac{z}{1-z}\right)$ とをデータにして, 線型回 帰モデルで推定する。

\section{2 理想方向型}

理想方向型は, 1 つのLogit曲線または線型の関数 で表現できる。希望家顀が 10 万円の場合の家顀 $(0<$ $x ）$ の満足度を表すメンバーシップ関数を例に説明す る。評価基準全体で, たとえば理想点の満足度 $e_{I}$ を Logit曲線では 0.95 , 線型では, 1.0で揃える。満足点 $e_{G}$ を 0.7 とする.また, 一対比較值は, 等比的に割り 当てるとする.

（1）一対比較を行う $Y^{k}$ の要素を選択する. 家賃の 例では，10万円が希望なので，その家貨で借り ることができれば満足なので満足点を10万円， 8 万円で借りることができれば理想的として 8 万円を理想点とした，2点以外にも，多少不満 な部分の評価值を求めるために，12，14万円 を代替案に加えた。

（2）一対比較を行う。家債の例では，4つの要素間 で，10万円が希望という条件の下で一対比較を 行う (表 5 ).

(3) $w_{I}^{*}=e_{I}, w_{G}^{*}=e_{G}$ になる $r$ を同定する.

（4） $z_{i}=w_{i}^{*}$ として, 表 6 を求め, 回帰分析より, 線 型の場合 $a=-0.0000170, b=2.349$, Logit曲線 の場合 $\beta=-9.91, \alpha=114.8$ となる.眓 6 は, それぞれの場合のグラフである。

また，それぞれの同定結果から，データと推定点の 差の 2 乗和を計算すると, 線型では 0.0317, Logit曲 線では0.0026になる。
表 5 家賃の一対比較

\begin{tabular}{|c|c|c|c|c|c|}
\hline$c_{12}$ & $c_{13}$ & $c_{14}$ & $c_{23}$ & $c_{24}$ & $c_{34}$ \\
\hline-5 & -6 & -8 & -6 & -5 & -2 \\
\hline
\end{tabular}

代替案の番号 $1: 8$ 万, $2: 10$ 万, $3: 12$ 万, $4: 14$ 万

表 6 家賃の例

\begin{tabular}{|c||c|c|c|c|}
\hline $\mathrm{NO}(\mathrm{i})$ & 1 & 2 & $3(\mathrm{G})$ & $4(\mathrm{I})$ \\
\hline \hline$y_{i}$ & 140000 & 120000 & 100000 & 80000 \\
\hline 線型用 $z_{i}$ & 0.0459 & 0.1571 & 0.7000 & 1.0000 \\
\hline $\operatorname{Logit~} 7 z_{i}$ & 0.0782 & 0.2107 & 0.7000 & 0.9500 \\
\hline $\log \left(x_{i}\right)$ & 11.850 & 11.695 & 11.513 & 11.290 \\
\hline Logit 用 $\log \left(\frac{z}{1-z}\right)$ & -2.4669 & -1.3206 & 0.8473 & 2.9444 \\
\hline
\end{tabular}
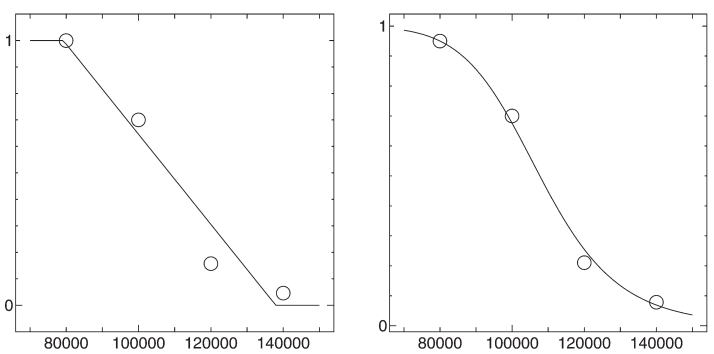

図 6 家賃のメンバーシップ関数 (左：線型, 右：Logit)

\section{3 理想点型}

理想点型の場合, 理想点の左側の曲線と右側の曲線 を別個に同定する，別個に同定する場合，理想点は左 右共通にし, その他の点は別個に一対比較の対象の要 素を選択する. 夏の適当な室温の満足度の同定の例で は，右側のための $\{26,28,30,32,34\}$, 左側のため の $\{26,24,22,20,18\}$ を使った.

理想点型の場合，同定した個別評価関数が，点 $\left(y_{I}, e_{I}\right)$ を通ることが重要なことが多い.しかし, 回 帰分析の場合, 点 $\left(y_{I}, e_{I}\right)$ から多少外れることがあ る。そこで, 回帰分析を行うとき, $\left(y_{I}, e_{I}\right)$ を必ず通 るように，パラメータを同定する。線型の場合， $z_{I}=$ $a y_{I}+b, \operatorname{Logit}$ 曲線の場合 $\log \left(\frac{z_{I}}{1-z_{I}}\right)=\alpha+\beta \log \left(y_{I}\right)$ と いう制約をつけて， $(a, b)$ または $(\alpha, \beta)$ を推定す る。この場合, 次式でパラメータを推定する.

$a=\quad \frac{\sum\left\{\left(y_{i}-y_{I}\right)\left(z_{i}-z_{I}\right)\right\}}{\sum\left(y_{i}-y_{I}\right)^{2}}$

$\beta=\frac{\sum\left\{\left(\log y_{i}-\log y_{I}\right)\left(\log \frac{z_{i}}{1-z_{i}}\right)-\log \frac{z_{I}}{1-z_{I}}\right\}}{\sum\left(\log y_{i}-\log z_{I}\right)^{2}}$

理想点型の場合, 左右対称の場合と非対称の場合が 考えられる。対称の場合, 片方のみ同定すればよいの で, 片側のみ一対比較を行う。非対称の場合, 左右 

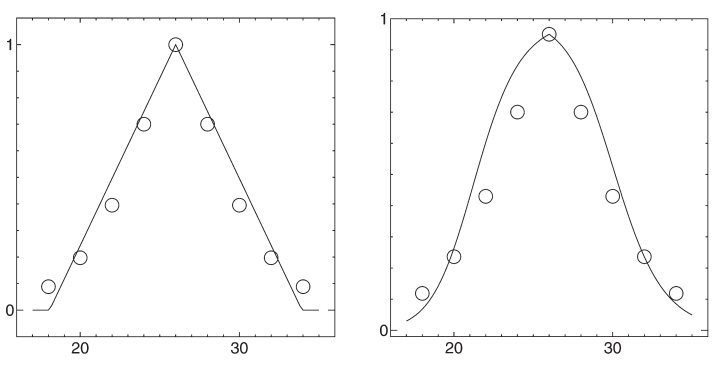

図 7 夏の快適な室温（左：線型, 右：Logit）

別々に同定する。困 7 は, 左右対称での快適な室温に ついてのメンバーシップ関数の同定結果である.

\section{4 理想区間型}

理想区間型の理想点との違いは次の点である.

- 理想点は, 左右別々に選択する。左の理想点は, 台形の上底の左端, 右の理想点は上底の右端に相 当する.

・同定する曲線は, 理想点を必ず通る必要はない.

・眓8のように $e_{I}$ の值を越えることがある. $e_{I}$ の 值で頭切りをすることも可能である.

困 8 は, 左右非対称の場合の例で,「青年」の個別評価 関数である。理想点は, 18 と 28 とし。

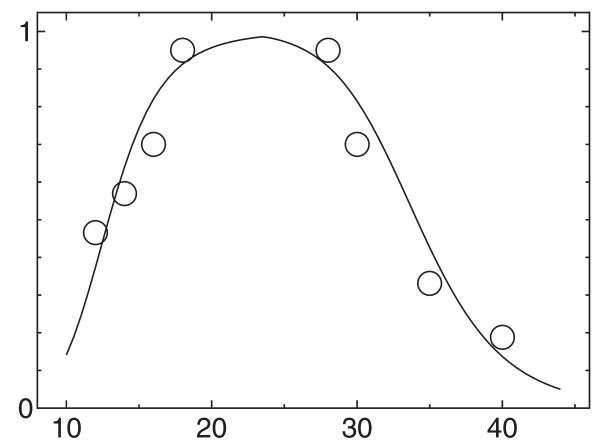

図 8 青年の個別評価関数（Logit）

\section{7. おわりに}

理想点と満足点の選択と一対比較を利用して，ショ ケ積分の入力值を同定する方法を提案した。一対比較 を利用しているので, 外的な基準がない主観的な対象 の評価を行うとき，本手法は有用であろう。しかし， さまざまな問題が残っている。たとえば，理想点，満 足点の代替案を探し出すことは難しい. しかし, 本手
法を使うことにより，ある程度客観的かつファジィ積 分の入力值の条件を満たす非積分関数を求めることが できる。

\section{謝辞}

この研究は，2006年度専修大学研究助成「ファジィ 積分モデルによる人間の評価構造推定法に関する研 究」の成果である。

\section{参 考 文 献}

[ 1 ] T.L.Saaty, The Analytic Hierarchy Process, McGraw - Hill, 1980.

[ 2 ] 刀根薫, 「ゲーム感覚意思決定法 - AHP 入門-」, 日科 技連出版社，1986.

[ 3 ] P.T.Harker, Alternative modes of questioning in the Analytic Hierarchy Process, Math. Modelling, 9, 353 -360, 1987.

[ 4 ] P.T.Harker and L.G.Vargas, The theory of ratio estimation: Saaty's analytic hierarchy process, Management Sci., 33, 1383-1403, 1987.

[5] 中島信之, AHPに打ける一対比較行列の整合性の考 察，富大経済論集，37,123-138，1991.

[6] 中村和男, メンバーシップ関数の測定諸手法の関連に ついて,第 2 回ノンエンジニアリングファジィワーク ショップ講演論文集, 66-67, 1992.

[ 7 ] 竹田英二, ファジィ理論と AHP in「社会科学の数理 ファジィ理論入門」, 裳華房, 235-248, 1994 .

[8] 高萩栄一郎, 室伏俊明, ファジィ測度の同定につい て, 第 5 回インテリジェント・システム・シンポジウ ム (FAN Symposium '95) 講演論文集, 日本ファジィ 学会, 463-468, 1995.

[9] 吉川歩, ファジィ評定とメンバーシップ関数同定法, 日本ファジィ学会誌，10，2，184-192，1998.

[10］高萩栄一郎, 一対比較法を利用したファジィ積分の入 力值の同定,第 8 回曖昧な気持ちに挑むワークショッ プ講演論文集，CD-ROM，2003.

(2006年 8 月15日 受付) （2006年10月26日＼cjkstart採録）

[問い合わせ先]

干214-8580 神奈川県川崎市多摩区東三田2-1-1

専修大学商学部

高萩 栄一郎

TEL : 044-900-7988

FAX : 044-900-7849

E-mail : takahagi@isc.senshu-u.ac.jp 


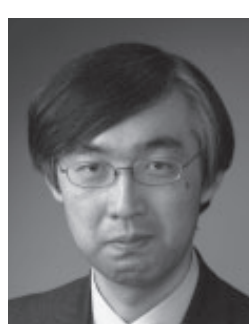

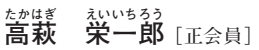

1961年東京都生まれ。1985年中央 大学経済学部卒業. 1989年中央大学 経済学研究科博士課程退学. 福井工業 大学経営工学科助手を経て, 現在, 専 修大学商学部教授. ファジィ測度, 積 分の研究に従事. 日本知能情報ファ ジィ学会, 日本オペレーションズ・リ サーチ学会, 日本経営数学会, IFSA 等の会員.

\section{Identifying $f$ in Choquet Integral (C) $\int f d \varkappa$ using Pairwise Comparision \\ by}

\section{Eiichiro TAKAHAGI}

\section{Abstract :}

We propose an identification method of $f$ in Choquet integral (C) $\int f d \mu$ using pairwise comparision. In many cases, the comparison words used by AHP are assigned fixed comparison values. Our experiments show that the correspondence table's parameter among the comparisons words and the comparison values change by the comparison objects. Input values of Choquet integral should have same evaluation unit among all evaluation criteria. In our methods, examinees reply not only pairwise comparisons, but also ideal and satisfaction points. By varying the correspondence parameter, all satisfaction and ideal point's values have the same values in the evaluation criteria. Lastly, we show some numerical examples that are domain sets are finite discrete set and continuous values sets.

Keywords : Choquet Integrals, Evaluation Unit, Pairwise Comparisons, Satisfaction Point, Ideal Point

\section{Contact Address : Eiichiro TAKAHAGI}

Sneshu University, School of Commerce

Higasi-mita 2-1-1, Takamu, Kawasaki, 214-8580, JAPAN

TEL : $044-900-7988$

FAX : $044-900-7849$

E-mail : takahagi@isc.senshu-u.ac.jp 